\title{
Association between Toll-like receptor 4 Asp299Gly polymorphism and coronary heart disease susceptibility
}

\author{
B.W. Wu*, J. Zhu*, H.M. Shi, B. Jin and Z.C. Wen \\ Department of Cardiology, Huashan Hospital, Fudan University, Shanghai, China
}

\begin{abstract}
Published data on the association between Toll-like receptor 4 (TLR4) Asp299Gly polymorphism and coronary heart disease (CHD) susceptibility are inconclusive. To derive a more precise estimation of the relationship, a meta-analysis was performed. English-language studies were identified by searching PubMed and Embase databases (up to November 2016). All epidemiological studies were regarding Caucasians because no TLR4 Asp/Gly and Gly/Gly genotypes have been detected in Asians. A total of 20 case-control studies involving 14,416 cases and 10,764 controls were included in the meta-analysis. Overall, no significant associations were found between TLR4 Asp299Gly polymorphism and CHD susceptibility in the dominant model (OR=0.89; $95 \% \mathrm{Cl}=0.74$ to $1.06 ; \mathrm{P}=0.20$ ) pooled in the meta-analysis. In the subgroup analysis by $\mathrm{CHD}$, non-significant associations were found in cases compared to controls. When stratified by control source, no significantly decreased risk was found in the additive model or dominant model. The present meta-analysis suggests that the TLR4 Asp299Gly polymorphism was not associated with decreased CHD risk in Caucasians.
\end{abstract}

Key words: Toll-like receptor 4; Polymorphism; Coronary heart disease; Meta-analysis

\section{Introduction}

Epidemiological studies have strongly supported a pivotal role for inflammatory, innate immune, and adaptive immune mechanisms in the pathogenesis of atherosclerosis $(1,2)$. Although the importance of Toll-like receptors (TLRs) in antimicrobial responses is established, the role in atherosclerotic disease is not well understood $(3,4)$. TLR4 is predominantly known for its role as an important mediator of innate immune response and has been implicated in the initiation, progression, and plaque destabilization stages of atherosclerosis (5). It is logical to consider that TLR4-mediated signaling might be a potential target for intervention in the initiation and progression of coronary heart disease (CHD).

Variants in the gene encoding TLR4 may affect the development of atherosclerosis accompanied by an impaired signal transduction, but the responsible polymorphisms remain inconclusive $(6,7)$. A single nucleotide polymorphism TLR4 Asp299Gly (rs4986790) has been reported to be associated with lower levels of proinflammatory serum markers, many of which have been implicated in atherosclerosis. Published studies on TLR4 Asp299Gly polymorphism and CHD susceptibility have generally revealed conflicting data, partially because of the possible weak effect of the polymorphism and the relatively small sample size in individual studies. Therefore, we performed a meta-analysis of the eligible studies to derive a more precise estimation of the association.

\section{Material and Methods}

\section{Search strategy}

This study was carried out and reported in agreement with the PRISMA guidelines for systematic reviews and meta-analyses (8). Each study was approved by the respective Institutional Ethics Committee. All patients had given written informed consent prior to study inclusion. Studies were identified by search of Medline and Embase databases using both electronic and manual search strategies. The comprehensive literature search was performed in October 2016 and updated in November 2016 with a verification search for any new studies. We combined search terms for Toll-like receptor 4 , polymorphism and coronary heart disease, and we restricted our search to studies that were published in English. When the studies were duplicated or overlapped, we included the most recently published studies in the final analysis.

Correspondence: B. Jin: <jinbo7711@aliyun.com> | Z.C. Wen: <wzchsh@aliyun.com>

*These authors contributed equally to this study.

Received January 20, 2017 | Accepted June 1, 2017 


\section{Inclusion criteria}

We independently evaluated eligible articles on the basis of the following inclusion criteria: 1) evaluation of TLR4 Asp299Gly polymorphism and CHD susceptibility, 2) case-control studies, and 3) sufficient published data for estimating an odds ratio (OR) with 95\% confidence interval $(\mathrm{Cl})$.

\section{Data extraction}

Two authors (B.W. Wu and J. Zhu) independently extracted data from all eligible studies fulfilling the inclusion criteria. Disagreement was resolved by discussion between the two authors. If these two authors could not reach a consensus, another author (H.M. Shi) was consulted and a final decision was made by the majority of the votes. Data extraction included the first author's surname, publication year, origin region, matching criteria, demographic data, and genotyping method. For data not provided in the main text, the required information was obtained in part from supplementary online appendixes.

\section{Statistical methods}

Cochrane collaboration meta-analysis review methodology was used for this study (9). ORs with $95 \% \mathrm{Cl}$ were used to assess the strength of association between TLR4 Asp299Gly polymorphism and CHD risk. The pooled ORs were performed for additive model and dominant model. The heterogeneity across trials was evaluated. P-values less than 0.10 for the $Q$ test indicated statistical heterogeneity among studies, and the overall effect estimate was calculated by the random-effect model. Otherwise, the fixed-effect model was used. All statistical tests were performed with RevMan version 4.2.2 available free from Cochrane Collaboration (http://www.cochrane.org/ cochrane/hbook/htm).

\section{Results}

\section{Study identification}

A total of 324 unique citations were identified by our search strategy. After the initial screening, 56 potentially relevant articles were selected for further review. Among these, 36 articles were excluded according to the inclusion criteria. Overall, 20 case-control studies involving 14,416 cases and 10,764 controls were included in the metaanalysis (10-29).

\section{Study characteristics}

Table 1 presents the characteristics of the 20 casecontrol studies published between 2003 and 2015. All molecular epidemiological studies were regarding Caucasians in the present meta-analysis because no TLR4 Asp/Gly

Table 1. Main characteristics of all case-control studies included in the meta-analysis.

\begin{tabular}{|c|c|c|c|c|c|c|c|}
\hline Authors & Year & Region & Matching criteria & Cases & Controls & Case/Control & Genotyping method \\
\hline Ameziane et al. (10) & 2003 & France & Age and sex & MI/UA & Healthy subjects & $183 / 216$ & TaqMan \\
\hline Balistreri et al. (11) & 2004 & Italy & Age & $\mathrm{MI}$ & Healthy subjects & $105 / 127$ & AS-PCR \\
\hline Berg et al. (12) & 2009 & Norway & - & $\mathrm{CHD}$ & CHD-free subjects & $130 / 100$ & PCR-RFLP \\
\hline Boekholdt et al. (13) & 2003 & Netherlands & Age & $\mathrm{Ml}$ & Non-MI subjects & $312 / 343$ & AS-PCR \\
\hline Džumhur et al. (14) & 2012 & Croatia & Age and sex & Ml & Healthy subjects & $119 / 120$ & TaqMan \\
\hline Edfeldt et al. (15) & 2004 & Sweden & Age and sex & Ml & Healthy subjects & $1172 / 1517$ & TaqMan \\
\hline Enquobahrie et al. (16) & 2008 & USA & Age and sex & $\mathrm{Ml}$ & Non-MI subjects & $848 / 2682$ & AS-PCR \\
\hline Golovkin et al. (17) & 2014 & Russia & Age and sex & $\mathrm{CHD}$ & Healthy subjects & $702 / 300$ & TaqMan \\
\hline Guven et al. (18) & 2015 & Turkey & - & $\mathrm{CHD}$ & CHD-free subjects & $150 / 150$ & PCR-RFLP \\
\hline Hamann et al. (19) & 2005 & UK & Age and sex & $\mathrm{CHD}$ & Healthy subjects & $388 / 189$ & TaqMan \\
\hline Hernesniemi et al. (20) & 2006 & Finland & - & $\mathrm{CHD}$ & CHD-free subjects & $333 / 299$ & AS-PCR \\
\hline Holloway et al. (21) & 2005 & UK & Age & MI & Non-MI subjects & $586 / 492$ & ARMS-PCR \\
\hline Koch et al. (22) & 2006 & Germany & - & $\mathrm{Ml}$ & CHD-free subjects & $3657 / 1211$ & TaqMan \\
\hline Kolek et al. (23) & 2004 & USA & - & $\mathrm{CHD}$ & CHD-free subjects & $1375 / 519$ & TaqMan \\
\hline Martinez-Rios et al. (24) & 2013 & Mexico & - & ACS & Healthy subjects & $457 / 283$ & TaqMan \\
\hline Morange et al. (25) & 2004 & $\begin{array}{l}\text { France/ } \\
\text { Ireland }\end{array}$ & Age & $\mathrm{CHD}$ & CHD-free subjects & $247 / 490$ & AS-PCR \\
\hline Nebel et al. (26) & 2007 & Germany & Age & $\mathrm{Ml}$ & Healthy subjects & $606 / 323$ & TaqMan \\
\hline O’Halloran et al. (27) & 2006 & Ireland & - & $\mathrm{CHD}$ & Healthy subjects & $1598 / 386$ & AS-PCR \\
\hline Yang et al. (28) & 2003 & UK & - & $\mathrm{CHD}$ & CHD-free subjects & $1078 / 322$ & ARMS-PCR \\
\hline Zee et al. (29) & 2005 & USA & Age and smoking & $\mathrm{MI}$ & CHD-free subjects & $370 / 695$ & AS-PCR \\
\hline
\end{tabular}

ARMS: amplification refractory mutation system; AS-PCR: allele-specific polymerase chain reaction; CHD: coronary heart disease; ACS: acute coronary syndrome; MI: myocardial infarction; RFLP: restriction fragment length polymorphism; UA: unstable angina; UK: United Kingdom, USA: United States of America. 
and Gly/Gly genotypes were detected in Asians $(30,31)$. Controls were mainly matched for sex and age, nine studies were population-based, and eleven studies were hospital-based.

\section{Main results}

Table 2 presents the main results of pooled ORs in the meta-analysis. Overall, no significant associations were found between TLR4 Asp299Gly polymorphism and CHD susceptibility in the dominant model (OR=0.89; $95 \%$ $\mathrm{Cl}=0.74$ to 1.06 ; $\mathrm{P}=0.20$, Figure 1 ) after the meta-analysis. The heterogeneity test indicated statistically significant results $\left(I^{2}=70.9 \%\right.$; $\left.P<0.00001\right)$. In the subgroup analysis by $\mathrm{CHD}$, non-significant associations were found. When stratified by control source, no significantly decreased risk was found in dominant model.
As depicted in Figure 2, no significantly decreased risk was found in the meta-analysis of TLR4 Asp299Gly polymorphism (Asp/Gly vs Asp/Asp) from 13 case-control studies $(\mathrm{OR}=0.89 ; 95 \% \mathrm{Cl}=0.71$ to $1.13 ; \mathrm{P}=0.35)$. As shown in Figure 3, no statistically significant associations were found in the relationship of TLR4 Asp299Gly polymorphism (Gly/Gly vs Asp/Asp) in patients with CHD compared with controls $(\mathrm{OR}=1.12 ; 95 \% \mathrm{Cl}=0.60$ to 2.07; $\mathrm{P}=0.72)$. In the subgroup analysis by $\mathrm{CHD}$ and control source, non-significant associations were found in additive model.

\section{Sensitivity analysis}

A single study involved in the meta-analysis was deleted each time to reflect the influence of the individual data-set to the pooled ORs, and the corresponding ORs

Table 2. Summary of pooled ORs according to TLR4 Asp299Gly polymorphism in coronary heart disease patients.

\begin{tabular}{|c|c|c|c|c|c|c|c|}
\hline \multirow[t]{2}{*}{ Comparison } & \multirow[t]{2}{*}{ Study } & \multicolumn{2}{|c|}{ Asp/Gly vs Asp/Asp } & \multicolumn{2}{|c|}{ Gly/Gly vs Asp/Asp } & \multicolumn{2}{|c|}{ Dominant model } \\
\hline & & OR $(95 \% \mathrm{Cl})$ & $P$ value & OR $(95 \% \mathrm{Cl})$ & $P$ value & OR $(95 \% \mathrm{Cl})$ & $P$ value \\
\hline Total & 20 & $0.89(0.71 ; 1.13)$ & 0.35 & $1.12(0.60 ; 2.07)$ & 0.72 & $0.89(0.74 ; 1.06)$ & 0.20 \\
\hline \multicolumn{8}{|l|}{ Category } \\
\hline ACS (MI/UA) & 11 & $0.90(0.68 ; 1.20)$ & 0.48 & $0.94(0.42 ; 2.08)$ & 0.88 & $0.95(0.77 ; 1.19)$ & 0.68 \\
\hline CHD (mixed) & 9 & $0.86(0.56 ; 1.32)$ & 0.49 & $1.44(0.54 ; 3.85)$ & 0.47 & $0.82(0.60 ; 1.11)$ & 0.20 \\
\hline \multicolumn{8}{|l|}{ Control source } \\
\hline Hospital & 11 & $0.78(0.46 ; 1.30)$ & 0.34 & $1.28(0.52 ; 3.17)$ & 0.59 & $0.82(0.65 ; 1.05)$ & 0.11 \\
\hline Population & 9 & $0.93(0.70 ; 1.24)$ & 0.64 & $0.99(0.42 ; 2.30)$ & 0.98 & $0.97(0.75 ; 1.26)$ & 0.83 \\
\hline
\end{tabular}

ACS: acute coronary syndrome; CHD: coronary heart disease; MI: myocardial infarction; UA: unstable angina; OR: odds ratio; $\mathrm{Cl}$ : confidence interval.

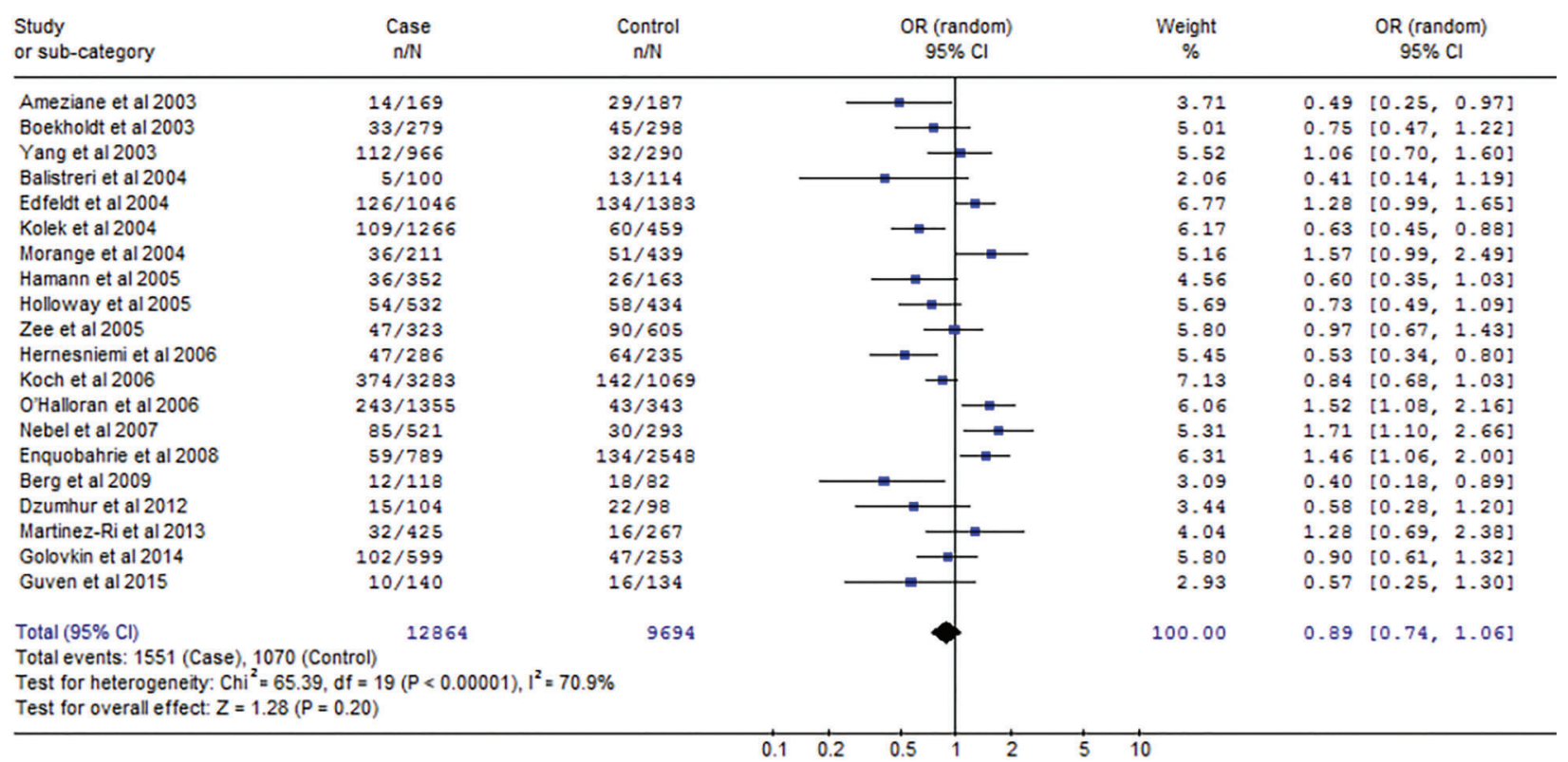

Figure 1. Cumulative odds ratio of TLR4 Asp299Gly polymorphism in patients with coronary heart disease compared with controls in dominant model $(\mathrm{OR}=0.89 ; 95 \% \mathrm{Cl}=0.74$ to $1.06 ; \mathrm{P}=0.20)$. See Table 1 for reference numbers of cited studies. 


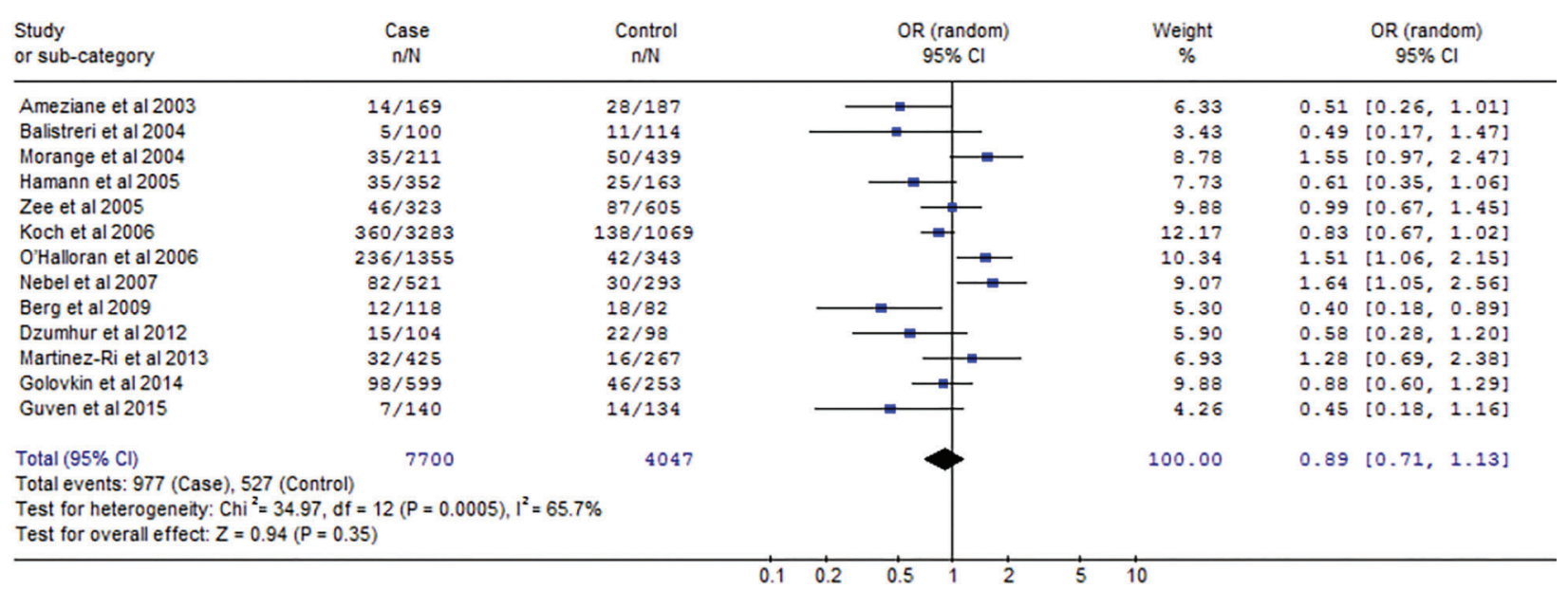

Figure 2. Forest plot for the meta-analysis of the association between TLR4 Asp299Gly polymorphism (Asp/Gly vs Asp/Asp) and coronary heart disease from 13 case-control studies $(O R=0.89 ; 95 \% \mathrm{Cl}=0.71$ to $1.13 ; \mathrm{P}=0.35)$. See Table 1 for reference numbers of cited studies.

\begin{tabular}{|c|c|c|c|c|c|c|}
\hline $\begin{array}{l}\text { Study } \\
\text { or sub-category }\end{array}$ & $\begin{array}{l}\text { Case } \\
\mathrm{n} / \mathrm{N}\end{array}$ & $\begin{array}{c}\text { Control } \\
\mathrm{n} / \mathrm{N}\end{array}$ & $\begin{array}{l}\text { OR (foxed) } \\
95 \% \mathrm{Cl}\end{array}$ & \multirow{2}{*}{$\begin{array}{c}\begin{array}{c}\text { Weight } \\
\%\end{array} \\
7.30\end{array}$} & \multicolumn{2}{|r|}{$\begin{array}{l}\text { OR (foxed) } \\
95 \% \mathrm{Cl}\end{array}$} \\
\hline Ameziane et al 2003 & $0 / 169$ & $1 / 187$ & 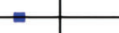 & & 0.37 & {$[0.01,9.06]$} \\
\hline Balistreri et al 2004 & $0 / 100$ & $2 / 114$ & & 11.95 & 0.22 & {$[0.01,4.72]$} \\
\hline Morange et al 2004 & $1 / 211$ & $1 / 439$ & $=$ & 3.32 & 2.09 & {$[0.13,33.51]$} \\
\hline Hamann et al 2005 & $1 / 352$ & $1 / 163$ & $=-$ & 7.00 & 0.46 & {$[0.03,7.43]$} \\
\hline Zee et al 2005 & $1 / 323$ & $3 / 605$ & 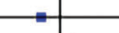 & 10.69 & 0.62 & {$[0.06,6.02]$} \\
\hline Koch et al 2006 & $14 / 3283$ & $4 / 1069$ & $-\frac{1}{5}$ & 30.87 & 1.14 & {$[0.37,3.47]$} \\
\hline O'Halloran et al 2006 & $7 / 1355$ & $1 / 343$ & $=$ & 8.16 & 1.78 & {$[0.22,14.48]$} \\
\hline Nebel et al 2007 & $3 / 521$ & $0 / 293$ & & 3.26 & 3.96 & {$[0.20,76.98]$} \\
\hline Martinez-Ri et al 2013 & $0 / 425$ & $0 / 267$ & & & \multicolumn{2}{|c|}{ Not estimable } \\
\hline Golovkin et al 2014 & $4 / 599$ & $1 / 253$ & & 7.17 & 1.69 & {$[0.19,15.23]$} \\
\hline Guven et al 2015 & $3 / 140$ & $2 / 134$ & & 10.27 & 1.45 & {$[0.24,8.79]$} \\
\hline \multicolumn{7}{|c|}{$\begin{array}{l}\text { Total events: } 34 \text { (Case), } 16 \text { (Control) } \\
\text { Test for heterogeneity: } C h i^{2}=3.47, \mathrm{df}=9(P=0.94), \mathrm{I}^{2}=0 \% \\
\text { Test for overall effect: } Z=0.35(P=0.72)\end{array}$} \\
\hline
\end{tabular}

Figure 3. Summary plot of TLR4 Asp299Gly polymorphism (Gly/Gly vs Asp/Asp) in patients with coronary heart disease compared with controls $(\mathrm{OR}=1.12 ; 95 \% \mathrm{Cl}=0.60$ to $2.07 ; \mathrm{P}=0.72)$. See Table 1 for reference numbers of cited studies.

were not significantly altered, indicating that our results were statistically robust (32).

\section{Publication bias}

Begg's funnel plot and Egger's test were performed to access the publication bias of the studies. The funnel-plot analysis indicated that no significant publication bias was detected to influence the results of this meta-analysis.

\section{Discussion}

Atherosclerosis, although closely related to lifestyle and environmental factors, is also influenced by the complex patterns of inheritance $(33,34)$. In the past decade, researchers have focused on numerous polymorphisms and mutations in genes that are related to atherosclerosis. However, the contribution of TLR4 to the development of $\mathrm{CHD}$ has been less well characterized. The major limitation of current genetic studies, applied to multifactorial diseases, is the lack of phenotypic markers identifying patient subgroups who may have a different prevalence of specific genetic or environmental factors. For this reason, our meta-analysis was performed to investigate the association between TLR4 Asp299Gly polymorphism and CHD.

The present study found non-significant associations between TLR4 Asp299Gly polymorphism and CHD susceptibility in 20 case-control studies. Considering the complex nature of atherosclerosis, it suggests that TLR4 Asp299Gly polymorphism has only a minor impact on the pathogenesis of $\mathrm{CHD}$. 
Compared with a previous meta-analysis (35), we included more case-control studies and performed subgroup analyses by stratification according to types of CHD and source of controls. In view of the negative results, some limitations of this meta-analysis should be acknowledged. First, the meta-analysis was not performed on individual patient data, so pre-specified data were partly extracted from studies for analysis. Second, as no TLR4 Asp/Gly and Gly/Gly genotypes have been detected in Asian populations, there was no study representing the Asian population. Third, the potential heterogeneity among trials, due to varying inclusion criteria, definition of variables, and different genotyping methods, also cannot be disregarded.

In conclusion, the present meta-analysis suggested that TLR4 Asp299Gly genetic polymorphism is not involved in the pathogenesis of CHD in Caucasians. However, despite the negative results, a causal

\section{References}

1. Kiech IS, Lorenz E, Reind IM, Wiedermann CJ, Oberhollenzer F, Bonora E, et al. Toll-like receptor 4 polymorphisms and atherogenesis. N Engl J Med 2002; 347: 185-192, doi: $10.1056 / N E J M o a 012673$.

2. Methe H, Kim JO, Kofler S, Weis M, Nabauer M, Koglin J. Expansion of circulating Toll-like receptor 4 positive monocytes in patients with acute coronary syndrome. Circulation 2005; 111: 2654-2661, doi: 10.1161/CIRCULATIONAHA. 104.498865.

3. Arslan F, deKleijn DP, Pasterkamp G. Innate immune signaling in cardiac ischemia. Nat Rev Cardio 2011; 8: 292-300, doi: 10.1038/nrcardio.2011.38.

4. Iwata $\mathrm{H}$, Nagai R. Novel immune signals and atherosclerosis. Curr Atheroscler Rep 2012; 14: 484-490, doi: $10.1007 /$ s11883-012-0267-7.

5. Labrum R, Bevan S, Sitzer M, Lorenz M, Markus HS. Toll receptor polymorphisms and carotid artery intima-media thickness. Stroke 2007; 38: 1179-1184, doi: 10.1161/01. STR.0000260184.85257.2b.

6. Pasterkamp G, Van Keulen JK, De Kleijn DP. Role of Tolllike receptor 4 in the initiation and progression of atherosclerotic disease. Eur J Clin Inves 2004; 34: 328-334, doi: 10.1111/j.1365-2362.2004.01338.x.

7. den Dekker WK, Cheng C, Pasterkamp G, Duckers HJ. Toll like receptor 4 in atherosclerosis and plaque destabilization. Atherosclerosis 2010; 209: 314-320, doi: 10.1016/ j.atherosclerosis.2009.09.075

8. Liberati A, Altman DG, Tetzlaff J, Mulrow C, Gøtzsche PC, loannidis JP, et al. The PRISMA statement for reporting systematic reviews and meta-analyses of studies that evaluate healthcare interventions: explanation and elaboration. PLOS Med 2009; 6: e1000100, doi: 10.1371/journal. pmed. 1000100 .

9. Lau J, loannidis JP, Schmid CH. Quantitative synthesis in systematic reviews. Ann Intern Med 1997; 127: 820-826, doi: 10.7326/0003-4819-127-9-199711010-00008.

10. Ameziane $\mathrm{N}$, Beillat $\mathrm{T}$, Verpillat $\mathrm{P}$, Chollet-Martin $\mathrm{S}$, Aumont MC, Seknadji $P$, et al. Association of the Toll-like receptor 4 relationship may exist in the development of atherosclerosis. Well-designed studies with larger samples should be conducted to confirm the results. Moreover, further studies estimating the effect of gene-gene and gene-environment interactions may eventually provide a better and more comprehensive understanding of the association between TLR4 Asp299Gly polymorphism and CHD susceptibility.

\section{Acknowledgments}

We gratefully acknowledge Dr. Ying Shan for her editorial suggestions. The principal investigator had full access to all data in the study and takes responsibility for the accuracy of the data analysis. This study was supported in part by grants from the National Natural Science Foundation in China (No.81100157 and No. 81470496).

gene Asp299Gly polymorphism with acute coronary events. Arterioscler Thromb Vasc Biol 2003; 23: e61-e64, doi: 10.1161/01.ATV.0000101191.92392.1D.

11. Balistreri CR, Candore G, Colonna-Romano G, Lio D, Caruso M, Hoffmann E, et al. Role of Toll-like receptor 4 in acute myocardial infarction and longevity. JAMA 2004; 292: 2339-2340.

12. Berg KK, Madsen HO, Garred P, Wiseth R, Gunnes S, Videm $V$. The additive contribution from inflammatory genetic markers on the severity of cardiovascular disease. Scand J Immunol 2009; 69: 36-42, doi: 10.1111/j.13653083.2008.02187.x.

13. Boekholdt SM, Agema WR, Peters RJ, Zwinderman AH, van der Wall EE, Reitsma PH, et al. Variants of toll-like receptor 4 modify the efficacy of statin therapy and the risk of cardiovascular events. Circulation 2003; 107: 2416-2421, doi: 10.1161/01.CIR.0000068311.40161.28.

14. Džumhur A, Zibar L, Wagner J, Simundić T, Dembić Z, Barbić J. Association studies of gene polymorphisms in toll-like receptors 2 and 4 in Croatian patients with acute myocardial infarction. Scand J Immunol 2012; 75: 517-523, doi: 10.1111/j.1365-3083.2012.02681.x.

15. Edfeldt $\mathrm{K}$, Bennet AM, Eriksson $\mathrm{P}$, Frostegård J, Wiman $B$, Hamsten A, et al. Association of hypo-responsive toll-like receptor 4 variants with risk of myocardial infarction. Eur Heart J 2004; 25: 1447-1453, doi: 10.1016/j.ehj.2004.05.004.

16. Enquobahrie DA, Smith NL, Bis JC, Carty CL, Rice KM, Lumley $\mathrm{T}$, et al. Cholesterol ester transfer protein, interleukin-8, peroxisome proliferator activator receptor alpha, and Toll-like receptor 4 genetic variations and risk of incident nonfatal myocardial infarction and ischemic stroke. Am J Cardiol 2008; 101: 1683-1688, doi: 10.1016/j.amjcard. 2008.02.052.

17. Golovkin AS, Ponasenko AV, Khutornaya MV, Kutikhin AG, Salakhov RR, Yuzhalin AE, et al. Association of TLR and TREM-1 gene polymorphisms with risk of coronary artery disease in a Russian population. Gene 2014; 550: 101-109, doi: 10.1016/j.gene.2014.08.022. 
18. Guven M, Ismailoglu Z, Batar B, Unal S, Onaran I, Karadag $B$, et al. The effect of genetic polymorphisms of TLR2 and TLR4 in Turkish patients with coronary artery disease. Gene 2015; 558: 99-102, doi: 10.1016/j.gene.2014.12.047.

19. Hamann L, Gomma A, Schröder NW, Stamme C, Glaeser C, Schulz $S$, et al. A frequent toll-like receptor (TLR)-2 polymorphism is a risk factor for coronary restenosis. J Mol Med 2005; 83: 478-485, doi: 10.1007/s00109-0050643-7.

20. Hernesniemi J, Lehtimäki T, Rontu R, Islam MS, Eklund C, Mikkelsson $\mathrm{J}$, et al. Toll-like receptor 4 polymorphism is associated with coronary stenosis but not with the occurrence of acute or old myocardial infarctions. Scand J Clin Lab Invest 2006; 66: 667-675, doi: 10.1080/003655106 00933011.

21. Holloway JW, Yang IA, Ye S. Variation in the toll-like receptor 4 gene and susceptibility to myocardial infarction. Pharmacogenet Genomics 2005; 15: 15-21, doi: 10.1097/0121 3011-200501000-00003.

22. Koch W, Hoppmann P, Pfeufer A, Schömig A, Kastrati A.Tolllike receptor 4 gene polymorphisms and myocardial infarction: no association in a Caucasian population. Eur Heart $J$ 2006; 27: 2524-2529, doi: 10.1093/eurheartj/ehl231.

23. Kolek MJ, Carlquist JF, Muhlestein JB, Whiting BM, Horne BD, Bair TL, et al. Toll-like receptor 4 gene Asp299Gly polymorphism is associated with reductions in vascular inflammation, angiographic coronary artery disease, and clinical diabetes. Am Heart $J$ 2004; 148: 1034-1040, doi: 10.1016/j.ahj.2004.05.049.

24. Martínez-Ríos MA, Vargas-Alarcón G, Vallejo M, CruzMartínez E, Pérez-Méndez O, Medina-Andrade Á, et al. Toll-like receptor 4 gene polymorphisms and acute coronary syndrome: no association in a Mexican population. Arch Cardiol Mex 2013; 83: 257-262.

25. Morange PE, Tiret L, Saut N, Luc G, Arveiler D, Ferrieres J, et al. TLR4/Asp299Gly, CD14/C-260T, plasma levels of the soluble receptor $\mathrm{CD} 14$ and the risk of coronary heart disease: The PRIME Study. Eur J Hum Genet 2004; 12: 1041-1049, doi: 10.1038/sj.ejhg.5201277.
26. Nebel A, Flachsbart F, Schäfer A, Nothnagel M, Nikolaus S, Mokhtari NE, et al. Role of the toll-like receptor 4 polymorphism Asp299Gly in longevity and myocardial infarction in German men. Mech Ageing Dev 2007; 128: 409-411, doi: 10.1016/j.mad.2007.04.001.

27. O'Halloran AM, Stanton A, O'Brien E, Shields DC. The impact on coronary artery disease of common polymorphisms known to modulate responses to pathogens. Ann Hum Genet 2006; 70: 934-945, doi: 10.1111/j.1469-1809.2006.00281.x.

28. Yang IA, Holloway JW, Ye S, Southampton Atherosclerosis Study (SAS) Group. TLR4 Asp299Gly polymorphism is not associated with coronary artery stenosis. Atherosclerosis 2003; 170: 187-190, doi: 10.1016/S0021-9150(03)00286-7.

29. Zee RY, Hegener HH, Gould J, Ridker PM. Toll-like receptor 4 Asp299Gly gene polymorphism and risk of atherothrombosis. Stroke 2005; 36: 154-157, doi: 10.1161/01.STR. 0000149948.31879.fO.

30. Kim YS, Hwang YJ, Kim SY, Yang SM, Lee KY, Parkle B. Rarity of TLR4 Asp299Gly and Thr399lle polymorphisms in the Korean population. Yonsei Med J 2008; 49: 58-62, doi: 10.3349/ymj.2008.49.1.58.

31. Yuan M, Xia J, Ma L, Xiao B, Yang Q. Lack of the Toll-like receptor 4 gene polymorphisms Asp299Gly and Thr399lle in a Chinese population. Int J Neurosci 2010; 120: 415-420, doi: 10.3109/00207451003778736.

32. Higgins JP, Thompson SG. Quantifying heterogeneity in a meta-analysis. Stat Med 2002; 21: 1539-1558, doi: 10.1002/ sim.1186.

33. Pranavchand R, Reddy BM. Current status of understanding of the genetic etiology of coronary heart disease. J Postgrad Med 2013; 59: 30-41, doi: 10.4103/0022-3859.109492.

34. Roberts R, Stewart AF. Genetics of coronary artery disease in the $21^{\text {st }}$ century. Clin Cardiol 2012; 35: 536-540, doi: $10.1002 / c l c .22002$.

35. Zhang K, Zhang L, Zhou B, Wang Y, Song Y, Rao L, et al. Lack of association between TLR4 Asp299Gly polymorphism and atherosclerosis: evidence from meta-analysis. Thromb Res 2012; 130: e203-e208, doi: 10.1016/j.thromres. 2012.07.008. 